\title{
RETREAT OF BARRY GLACIER, PORT WELLS, PRINCE WILLIAM SOUND, ALASKA, BETWEEN 1910 AND 1914.
}

By Bertrand L. Johnson.

The Barry Glacier, in the northwest corner National Geographic Society's expedition under of Prince William Sound (fig. 6), was first de- Lawrence Martin mapped and studied the front scribed by Glenn, ${ }^{1}$ Castner, ${ }^{2}$ and Mendenhall. ${ }^{3}$ It was more extensively studied by the Harriman Alaska expedition * in 1899 ; by Grant ${ }^{5}$ in 1905 ; by Grant and Higgins ${ }^{5}$ in 1908 and 1909; and by Martin ${ }^{6}$ in 1910. In 1899 Gannett made the first map which accurately delineated the front of the Barry Glacier. The front was remapped by Grant in 1905, by Grant and Higgins in 1908 and 1909, and by Martin in 1910. Numerous photographs were taken in these years, and several of them were reproduced in the reports cited. Tarr and Martin ${ }^{7}$ summarized the results of the earlier expeditions and gave an exhaustive treatment of the known life history of the Barry Glacier up to and including 1910. In 1899 the Barry Glacier nearly closed Doran Strait. (See FIGURE 6.-Map of the Port Wells district, Prince William Sound, A laska, showing location of Barry fig. 7.) In 1910, when the

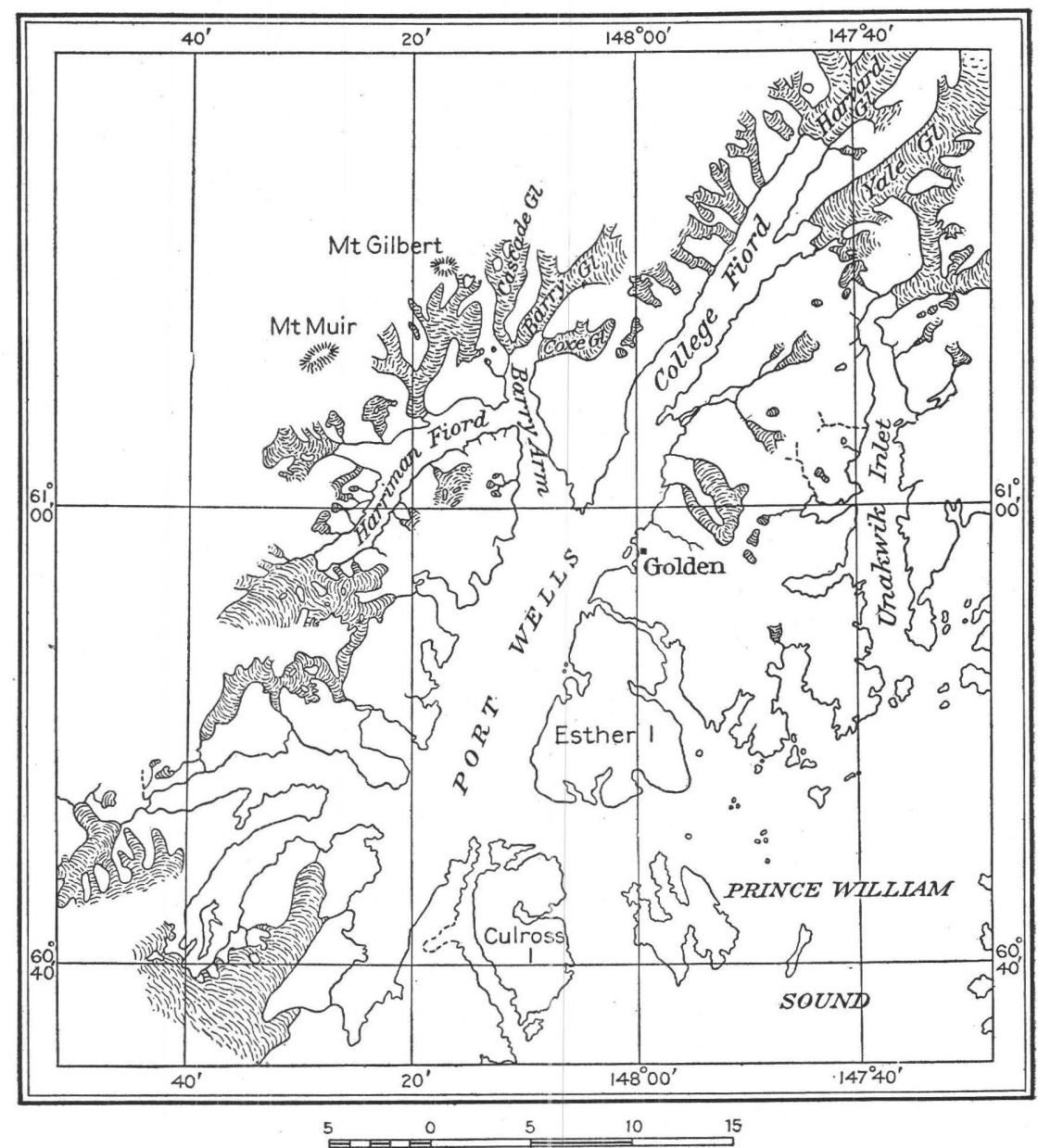
Glacier.

1 Glenn, E. F., Report on exploration in Alaska: U. S. War Dept., Adj. Gen. Office, No. 25, pp. 19, 21, 1899

2 Castner, J. C., idem, pp. 189, 191.

8 Mendenhall, W. C., A reconnaissance from Resurrection Bay to the Tanana River, Alaska, in 1898: U. S. Geol. Survey Twentieth Ann. Rept., pt. 7, p. 325, 1900.

4 Gannett, Henry, The Harriman Alaska Expedition: Nat. Geog. Mag., vol. 10, pp.510, 511, 1899; Am. Geog. Soc. Jour., vol.31, pp.355-356, 1899, Burroughs, John, Narrative of the expedition: Alaska, vol. 1, pp. 71-74. Harriman Alaska Expedition, 1902. Gannett, Henry, General geography:Idem, vol. 2, p. 263, 1902. Gilbert, G. K., Glaciers and glaciation: Idem, vol. 3, pp. 90-93, 176, 1904.

5 Grant, U. S., and Higgins, D. F., Glaciers of Prince William Sound and the southern part of the Kenai Peninsula, Alaska; II, Glaciers of

Port Wells, Prince William Sound: Am. Geog. Soc. Bull., vol. 43, pp.
327-331, 334, 1911; Coastal glaciers of Prince William Sound and Kenai Peninsula, Alaska: U. S. Geol. Survey Bull. 526, pp. 33-35, 1913. Reid, H. F., The variations of glaciers: Jour. Geology, vol. 14, pp. 406-407, 1906; vol. 17, p. 671, 1909.

${ }^{6}$ Martin, Lawrence, Crossing the Alaskan glaciers: Collier's, vol. 47, No. 17, p. 20, July 15, 1911; The National Geographic Society's researches in Alaska: Nat. Geog. Mag., vol. 22, pp. 550-551, 555, 556, 557, 559, 560, 1911; Gletscheruntersuchungen längs der Küste von Alaska: Petermanns Mitt., Jahrg. 58, pp. 82, 148-149, 1912. Reid, H. F., Les variations périodiques des glaciers, XVIme rapport,1910-Amérique du Nord: Zeitschr. Gletscherkunde, Bd. 6, Heft 2, pp. 101-102, 1911; The variations of glaciers: Jour. Geology, vol. 19, p. 458, 1911. Tarr, R. S., and Martin, Lawrence, Alaskan glacier studies, pp. 14, 317, 319-327, 348-349, 350, Nat. Geog. Soc., 1914

7 Tarr, R. S., and Martin, Lawrence, op. cit., pp. 318-327. 
of the glacier, it had retreated approximately 3 miles from the position occupied in 1899 .

The Barry Glacier was visited by the writer in 1913 and again late in the fall of 1914. Photographs were taken in both years, and four of these photographs are reproduced here (Pls. V and VI) for comparison with two photographs (Pl. IV) by Lawrence Martin, showing the position of the ice front in 1910 . The positions of the glacier front in 1899, 1905, 1908, 1909, 1910, 1913, and 1914 are shown in the accompanying sketch map (fig. 7).

The glacier front in 1910 stretched in a nearly straight line across Barry Arm (fig. 7

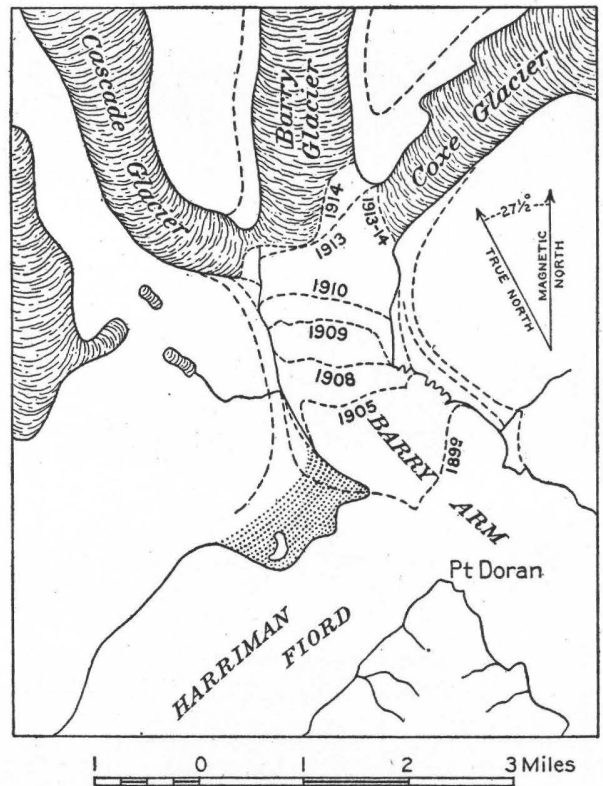

Figure 7.-Sketch map of Barry, Coxe, and Cascade glaciers, Prince William Sound, Alaska, showing position of glacier fronts in 1899 $1905,1908,1909,1910,1913$, and 1914 .

and Pl. IV). Between 1910 and 1913 the retreat of the glacier uncovered bedrock in the western part of the glacier front, near the left center of the view shown in Plate $\mathrm{V}, A$. No rock outcrops are visible in the photographs made in 1910 (Pl. IV), nor does Martin mention any exposed bedrock in the glacier front. As an apparent result of this uncovering of the bedrock surface the western part of the glacier front retreated less rapidly than the eastern part, and in 1913 a marked reentrant was noticeable along the east side of the glacier.
On this side the Barry Glacier had also retreated beyond the Coxe Glacier and was completely separated from it (Pls. V, $A$, and VI, $A$ ). The Barry and Cascade glaciers had partly separated (Pl. VI, A). The surface of the Barry Glacier at its outer end had also lowered, increasing the width of the bare zones at the sides of the glacier by an appreciable amount. The linear retreat along the east side of the glacier between 1910 and 1913 is estimated as about 6,500 feet; that along the west side as about 2,500 feet. The average annual retreat between 1910 and 1913 was thus slightly over 2,100 feet on the east side but only a little over 800 feet on the west side. The rate of retreat on the west side, however, was probably much greater prior to the exposure of bedrock in the glacier front, as between 1905 and 1910 the receding glacier preserved a nearly straight front across Barry Arm. The inference that the rate of retreat on the west side rapidly lessened after the uncovering of bedrock in that portion of the glacier front is borne out by the slight retreat at this point between 1913 and 1914 .

The photographs taken in the fall of 1914 show a continued withdrawal of the glacier, most rapidly along its east side, where the distance between the Barry and Coxe glaciers had increased conspicuously $(\mathrm{Pl} . \mathrm{V}, B)$. The retreat here between the dates in 1913 and 1914 on which the photographs were taken appeared to be about 1,700 feet. The bedrock in the western part of the Barry Glacier front was still visible, and appeared to be of about the same height as in 1913 but to have a slightly greater length along the glacier front. The ice at this point had apparently retreated but slightly since 1913. The separation of the Cascade and Barry glaciers was more nearly complete, and that part of the Cascade Glacier already separated from the Barry Glacier had retreated a short distance up the fiord wall $(\mathrm{Pl}$. VI, $B)$. The surface of the Barry Glacier was considerably lower, and that of the Coxe Glacier had lowered slightly. The total retreat of the Barry Glacier between 1910 and 1914 appeared to be about 8,200 feet along its eastern edge and a little more than 2,500 feet along its western edge. 


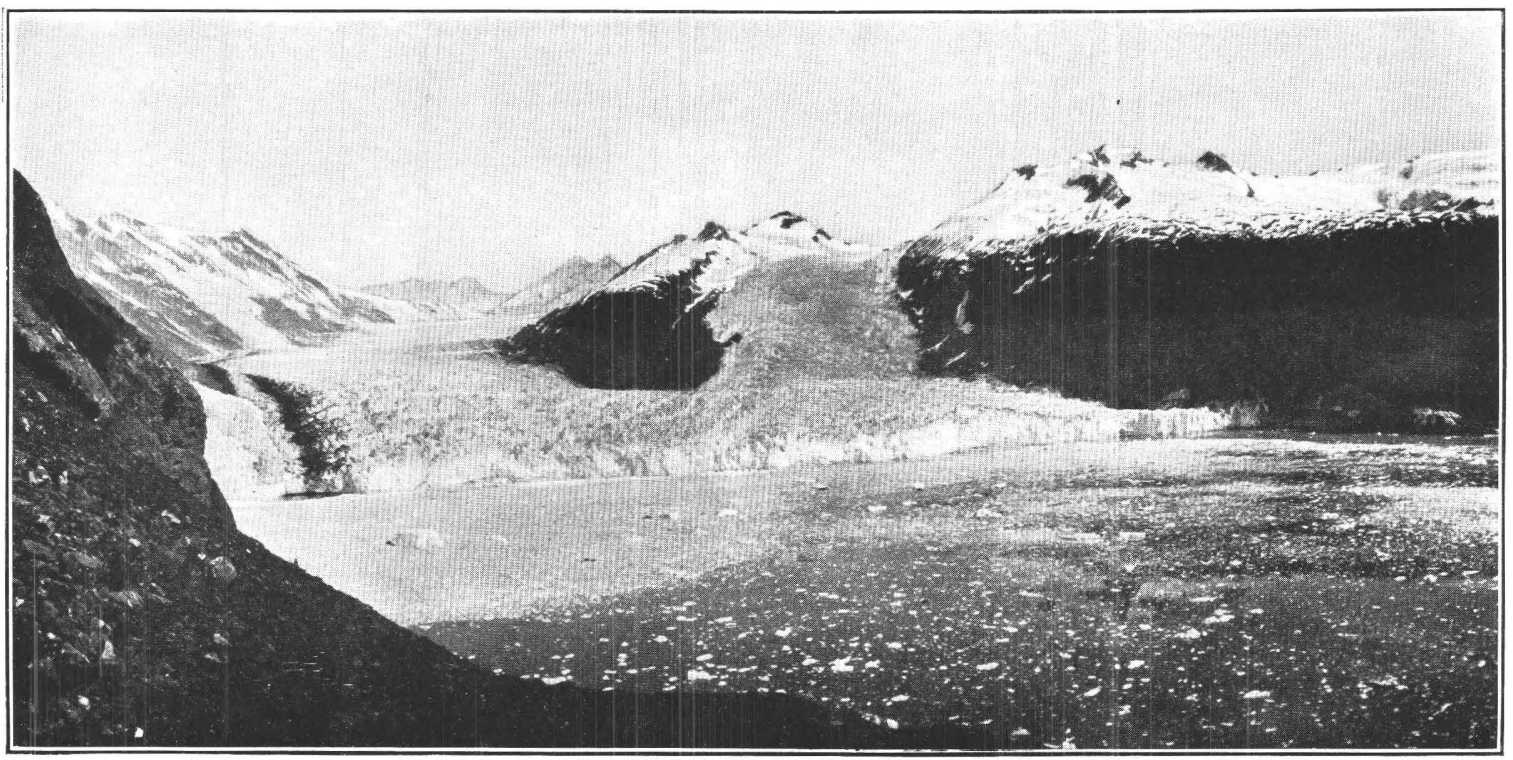

A. BARRY AND COXE GLACIERS, JULY 26, 1910.

Photograph by Lawrence Martin. Originally reproduced in Tarr and Martin's "Alaskan glacier studies." Used by courtesy of the National Geographic Society.

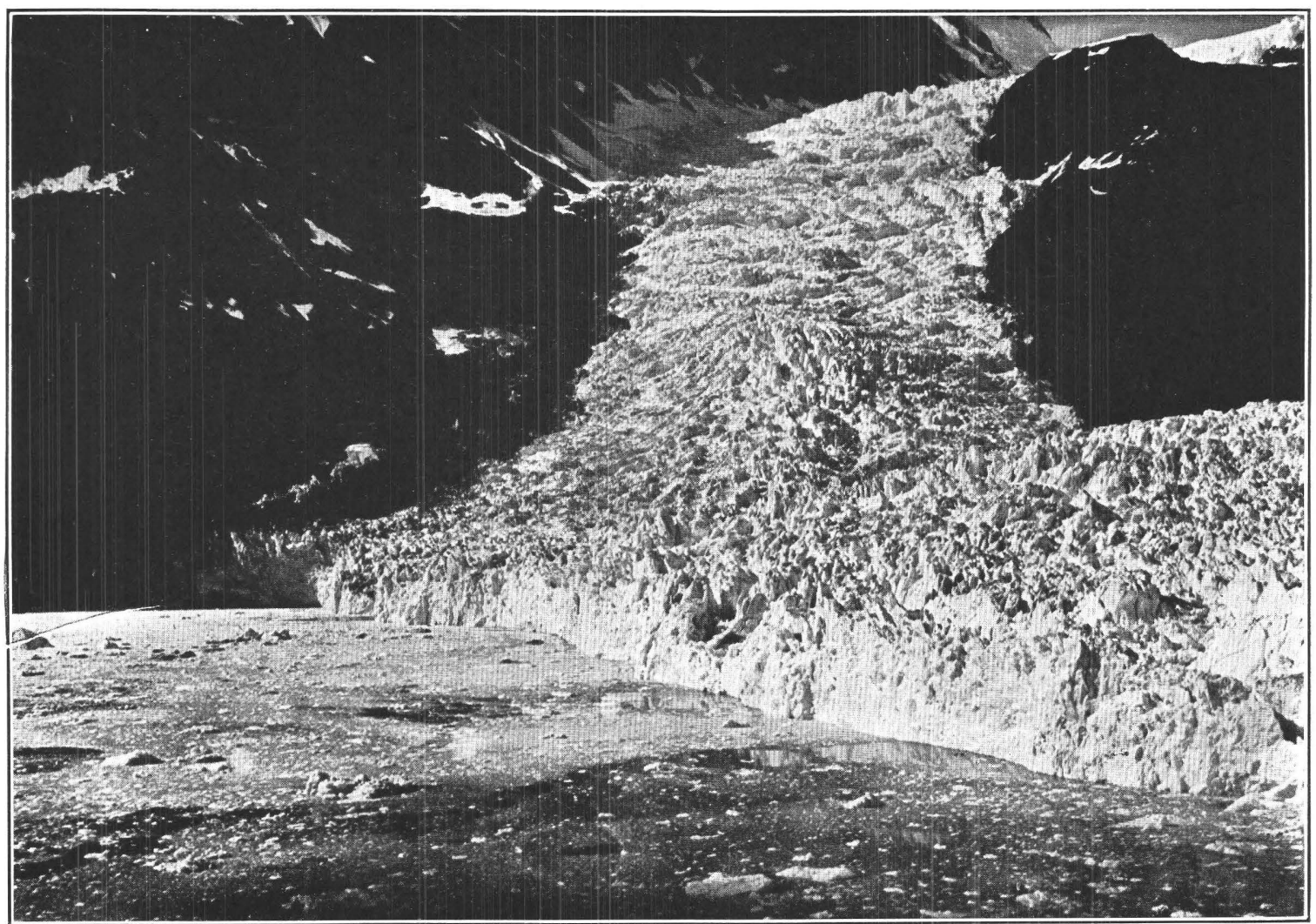

B. CASCADE GLACIER AT ITS JUNCTION WITH BARRY GLACIER, JULY 25, 1910.

Photograph by Lawrence Martin. Originally reproduced in Collier's, vol. 47, No. 17, July 15, 1911. 


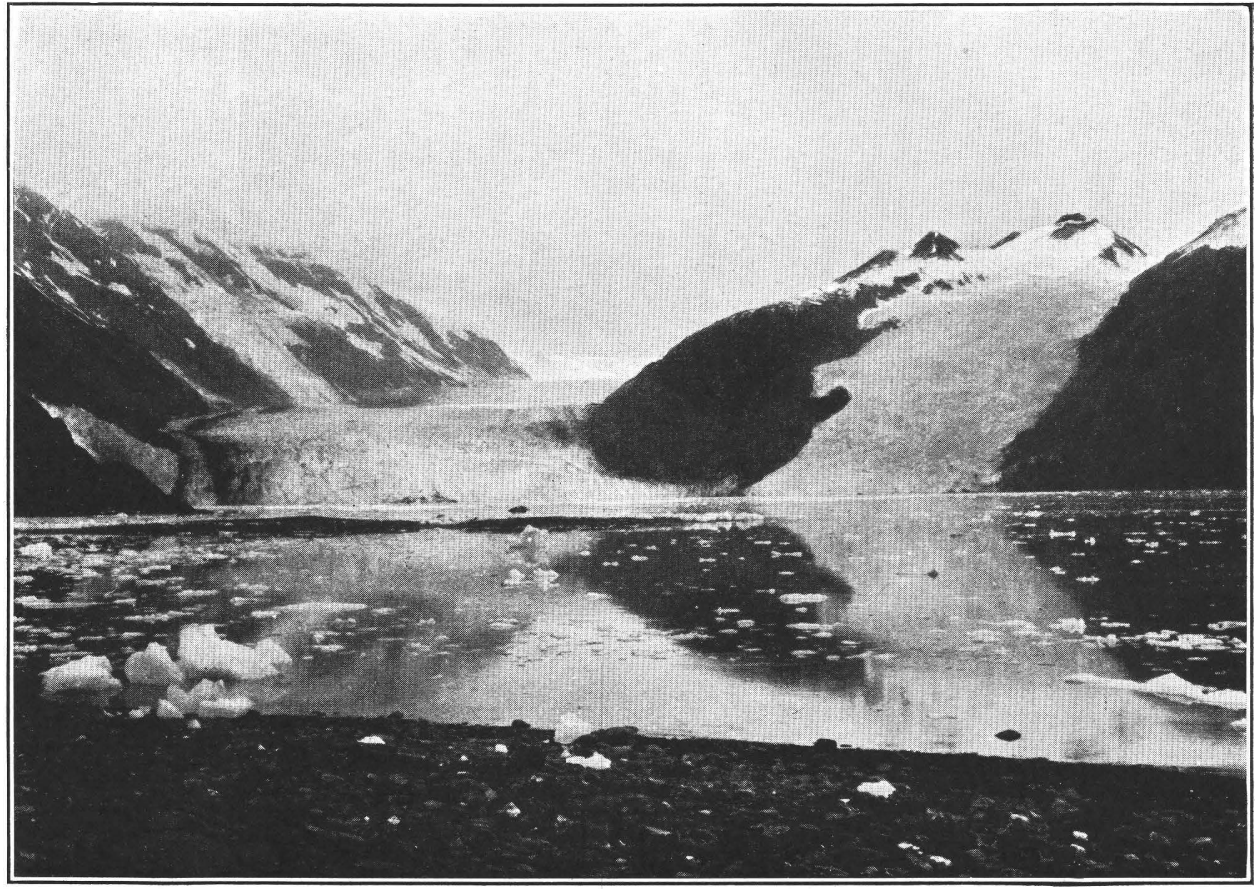

A. BARRY AND COXE GLACIERS, AUGUST 18, 1913.

From outwash plain formed by Barry Glacier in 1899. (See fig. 7.) Note outcrop of rock in front of Barry Glacier and separation of Barry and Coxe glaciers. Photograph by B. L. Johnson.

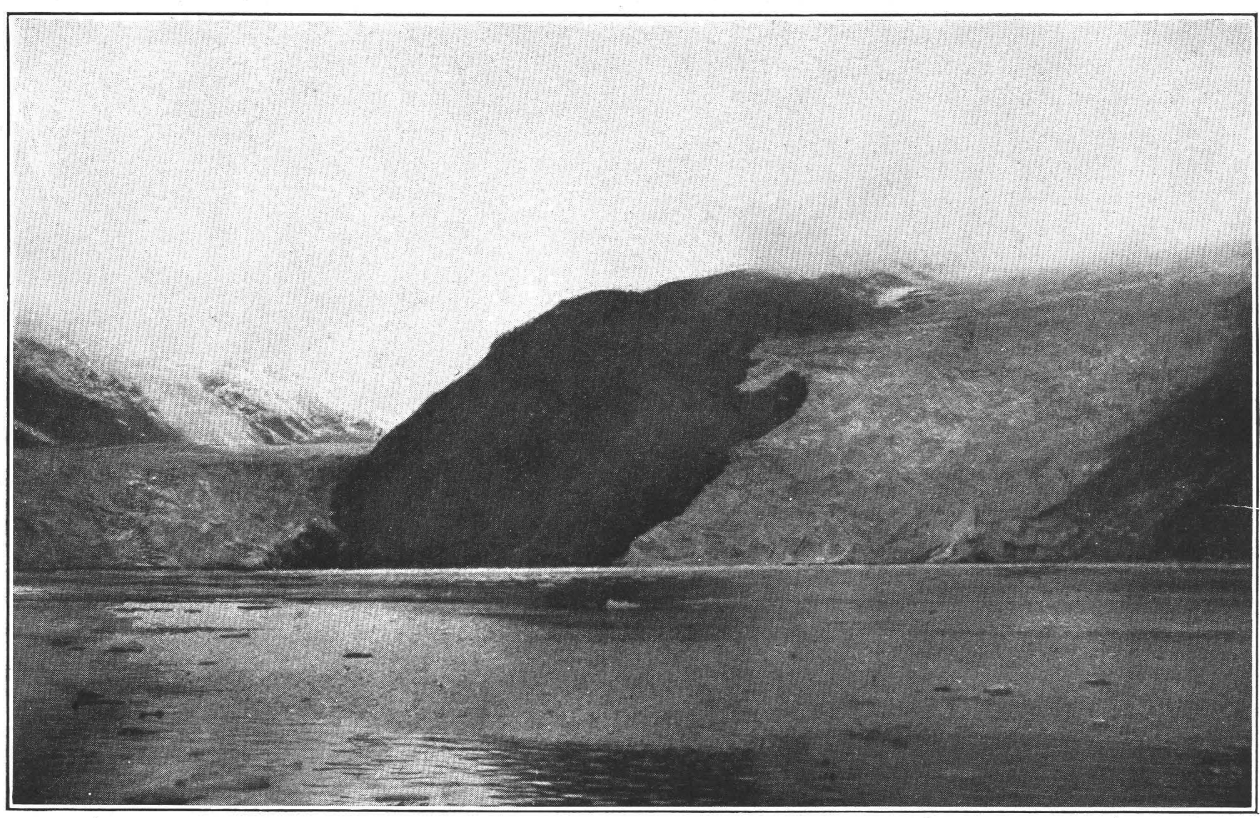

B. BARRY AND COXE GLACIERS, OCTOBER 5, 1914.

Glaciers are much more widely separated than in previous years. Photograph by B. L. Johnson, from deck of a launch. 


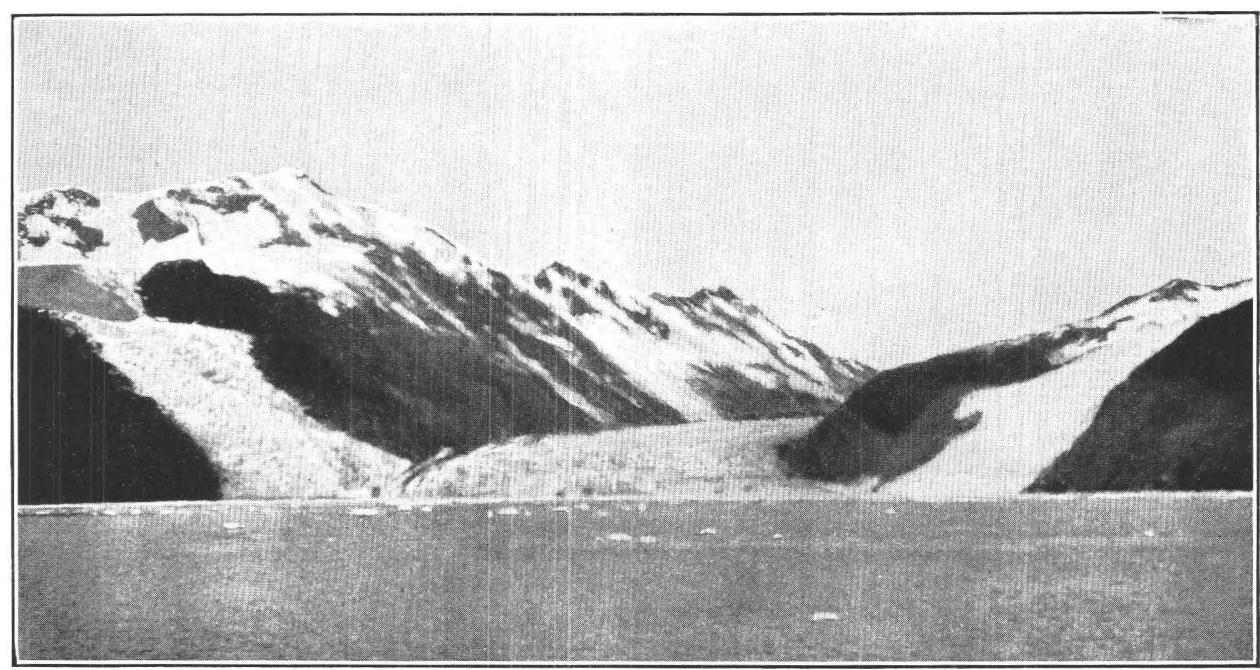

A. BARRY, COXE, AND CASCADE GLACIERS, AUGUST 15, 1913.

Photograph by B. L. Johnson, from deck of a launch.

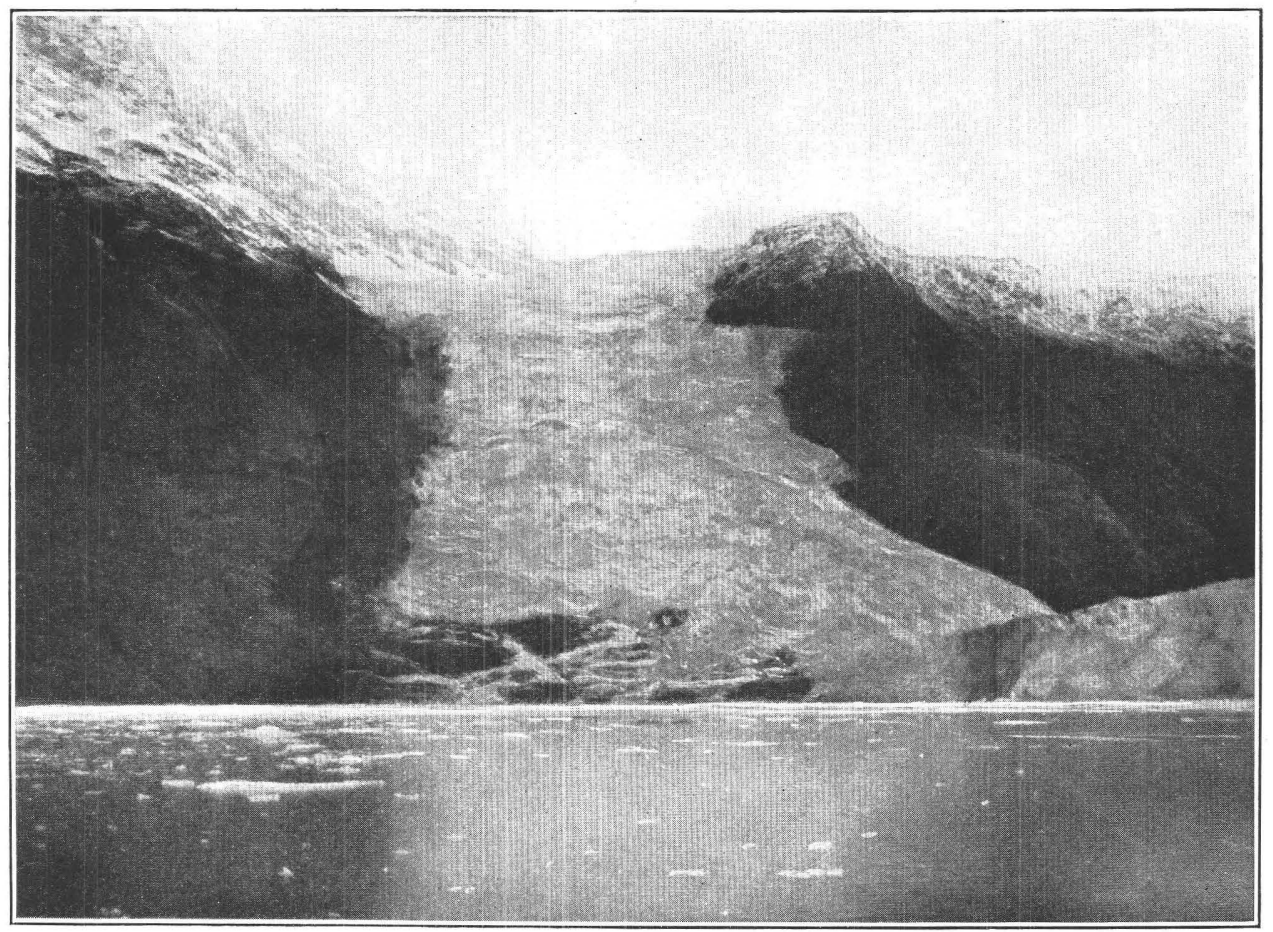

B. CASCADE GLACIER AT ITS JUNCTION WITH BARRY GLACIER, OCTOBER 5, 1914.

Glaciers are almost separated, and Cascade Glacier has begun to retreat up the fiord wall. Photograph by B. L. Johnson, from deck of a launch. 